\title{
PENERAPAN PEMBELAJARAN BERBASIS MASALAH UNTUK MENINGKATKAN AKTIVITAS DAN HASIL BELAJAR SISWA DALAM MEMAHAMI LINGKUNGAN HIDUP PADA MATA PELAJARAN IPS DI SMP NEGERI 2 SUKODONO
}

\author{
Bejo Apriyanto ${ }^{1}$, Elan Artono Nurdin', Fahrudi Ahwan Ikhsan ${ }^{1}$, Fahmi Arif Kurniawan ${ }^{1}$ \\ ${ }^{1}$ Program Studi Pendidikan Geografi, Fakultas Keguruan dan Ilmu Pendidikan, Universitas Jember \\ e-mail: apriyanto.bejo@unej.ac.id
}

\begin{abstract}
Abstrak
Berdasarkan hasil observasi yang dilakukan pada tanggal 5 April di kelas VIII-B SMP Negeri Sukodono diketahui bahwa 75\% siswa bahwa mata pelajaran IPS geografi membosankan karena terlalu banyak konsep yang harus dihafalkanmereka kurang memahami manfaat pelajaran geografi bagi kehidupan nyata, serta jarang melakukan observasi keluar kelas. Indikasi kuat yang melatarbelakangi kesulitan siswa untuk memahami materi yang disampaikan antara lain karena kurangnya kemampuan siswa dalam memecahkan masalah IPS Geografi. Hal tersebut dapat dilihat dari aktivitas serta hasil belajar siswa yang menunjukkan hanya ada 2 atau 5\% siswa yang terlihat aktif, sedangkan yang lain kurang aktif, serta kemampuan siswa dalam memecahkan masalah hanya ada 5 siswa yang dapat memecahkan masalah dengan baik. Kemampuan siswa dalam memecahkan masalah masih kurang hal ini dapat dilihat dari hasil observasi yang menyebutkan hanya terdapat 4 dari 40 siswa atau $10 \%$ yang bisa menyelesaikan masalah sedangkan yang $90 \%$ masih perlu bimbingan dan latihan dalam memecahkan masalah. Untuk mengatasi permasalahan kualitas pembelajaran, maka disusunlah pembelajaran geografi dengan mengimplementasikan pembelajaran berbasis masalah untuk meningkatkan aktivitas dan hasil belajar siswa dalam memahami permasalahan lingkungan hidup. Tujuan penelitian ini adalah untuk mendeskripsikan apakah dengan pembelajaran berbasis masalah dapat meningkatkan aktivitas dan hasil belajar siswa dalam memecahkan masalah lingkungan hidup di SMP Negeri 2 Sukodono. Penelitian ini merupakan penelitian tindakan kelas yang dilaksanakan dalam 2 siklus tindakan. Dalam penelitian ini data yang diperoleh berupa aktivitas belajar siswa, nilai hasil diskusi, dan nilai hasil belajar siswa. Aktivitas belajar siswa diukur berdasarkan peningkatan rata-rata persentase aktivitas belajar siswa dan taraf keberhasilan tindakan, kemudian nilai hasil diskusi siswa berdasarkan skor perolehan nilai hasil diskusi, sedangkan hasil belajar siswa diukur berdasarkan nilai hasil tes yang dilaksanakan pada akhir siklus. Instrumen yang digunakan yaitu soal tes, lembar observasi aktivitas belajar siswa dan catatan di lapangan serta dokumentasi. Hasil penelitian menunjukkan bahwa dengan penerapan pembelajaran berbasis masalah dapat meningkatkan aktivitas dan hasil belajar siswa dalam memahami permasalahan lingkungan hidup SMP Negeri 2 Sukodono ditunjukkan dengan peningkatan aktivitas belajar siswa dari 65,07\% (cukup) pada siklus I meningkat menjadi $76,67 \%$ (baik) pada siklus II. Peningkatan hasil diskusi siswa dapat diketahui rata-rata skor hasil diskusi siswa sebesar 57,18\% (cukup) pada siklus I meningkat menjadi 76,5\% (baik) pada siklus II. Peningkatan hasil belajar siswa dapat diketahui dari rata-rata nilai tes pada tiap akhir siklus sebesar 67,92\% (cukup) pada siklus I meningkat menjadi 71,1\% (baik) pada siklus II. Berdasarkan penelitian di atas guru mata pelajaran IPS geografi dalam pembelajaran geografi perlu dilakukan dengan menggunakan model pembelajaran berbasis masalah karena ini sangat mendukung untuk kemampuan berfikir kritis serta menimgkatkan kecerdasan dan hasil belajar.
\end{abstract}

Kata Kunci: pembelajaran berbasis masalah, aktivitas belajar, hasil belajar.

\section{PENDAHULUAN}

Kemajuan bangsa Indonesia hanya dapat dicapai melalui penataan pendidikan yang baik. Upaya peningkatan mutu pendidikan itu diharapkan dapat menaikkan harkat dan martabat manusia Indonesia. Untuk mencapai itu, pembaharuan pendidikan di Indonesia perlu terus dilakukan untuk menciptakan dunia pendidikan yang peka terhadap perubahan zaman. Upaya meningkatkan mutu pendidikan adalah fokus utama dalam pembangunan pendidikan dewasa ini. Efektivitas pembelajaran oleh guru professional adalah faktor utama peningkatan mutu pendidikan tersebut. Guru sebagai 
pendidik professional dengan tugas utama mendidik, mengajar, membimbing, mengarahkan, melatih, menilai dan mengevaluasi peserta didik membutuhkan peningkatan professional secara terus menerus. Di era kurikulum yang senantiasa mengalami pergeseran/perubahan ini, penyelenggara pendidikan dan pembelajaran membutuhkan guru yang juga berfungsi sebagai peneliti secara most power full, yakni guru yang mampu melaksanakan tugas dan mengadopsi strategi baru. Berdasarkan fungsi pendidikan nasional, maka peran guru menjadi kunci keberhasilan dalam misi pendidikan dan pembelajaran di sekolah selain bertanggung jawab untuk mengatur, mengarahkan, dan menciptakan suasanakondusif yang mendorong siswa untuk melakukan pembelajaran di dalam kelas. Permasalahan pendidikan selalu muncul bersamaan dengan berkembang dan meningkatnya kemampuan siswa, situasi, kondisi lingkungan yang ada, pengaruh informasi dan kebudayaan serta berkembangnya ilmu pengetahuan dan teknologi.SMP Negeri 2 Sukodono merupakan sekolah yang sudah maju, hal ini dapat dilihat dari sarana dan prasarana yang cukup lengkap di sekolah tersebut, yaitu antara lain Ruang Kegiatan Belajar, Laboratorium Fisika, Laboratorium Biologi, Laboratorium Komputer, Laboratorium Bahasa, Perpustakaan, Ruang Organisasi Siswa Intra Sekolah (OSIS), Ruang Koperasi Siswa, Ruang Unit Kesehatan Sekolah (UKS), Ruang Bimbingan Konseling (BK), Ruang Elektro, Ruang Keterampilan, Mushola dan Kantin Sekolah.

Berdasarkan hasil observasi yang dilakukan, diketahui bahwa guru mata pelajaran Geografi dalam menyampaikan materi pelajaran dengan menggunakan metode ceramah, tanya jawab, penugasan, dan latihan. Selain itu, berdasarkan wawancara yang dilakukan dengan siswa kelas VIII-B SMP Negeri 2 Sukodono tentang pandangan mereka terhadap pelajaran Geografi hampir sebagian besar siswa mengatakan bahwa mata pelajaran Geografi membosankan, karena banyak konsep yang harus dihafalkan (banyak hafalan). Selain itu, dari 40 siswa sebesar 75\% siswa kurang memahami manfaat pelajaran Geografi bagi kehidupan nyata. Hal ini terlihat dari jawaban siswa ketika diberi pertanyaan yang dikaitkan dengan permasalahan lingkungan yang ada disekitar mereka. Salah satu pendekatan pembelajaran yang berkembang sekarang adalah pendekatan pembelajaran yang menggunakan masalah dunia nyata sebagai konteks siswa untuk belajar tentang cara berfikir kritis, dan keterampilan memecahkan masalah, serta mamperoleh pengetahuan dan konsep yang esensial dari materi pembelajaran. Pendekatan pembelajaran berbasis masalah bertujuan untuk membentuk insan yang mandiri, karena dalam proses pembelajaran partisipasi siswa sangat diutamakan dan sangat ditonjolkan, selain itu keaktifan baik secara kognitif, efektif maupun psikomotorik dengan keterlibatan siswa secara penuh dalam proses pembelajaran akan terwujud keterampilan keterampilan, baik keterampilan intalektual, sosial maupun fisik yang berguna nanti dalam kehidupan nyata. Pembelajaran berbasis masalah juga mengorentasikan siswa kepada masalah/ pertanyaan yang autentik dan menuntut kerjasama dalam penyelidikan dan menghasilkan hasil karya.

\section{METODE}

Jenis penelitian ini adalah penelitian tindakan kelas (PTK), yaitu "penelitian yang dilakukan oleh seseorang yang bekerja mengenai apa yang sedang ia laksanakan tanpa mengubah sistem pelaksanaannya" (Arikunto,2002:3). Tindakan yang diberikan adalah memberikan tugas untuk merumuskan dan memecahkan masalah serta membuat laporan kemudian memberikan tes hasil belajar untuk mengetahui keberhasilan pembelajaran. Kegiatan peneliti adalah melakukan proses pembelajaran dengan menggunakan pembelajaran berbasis masalah untuk materi kerusakan lingkungan hidup dan penangulangannya. Pelaksanaan tindakan dalam penelitian ini akan dilakukan dalam beberapa siklus untuk mencapai taraf keberhasilan tindakan. Dalam setiap siklusnya terdiri dari 4 tahap kegiatan. Tahapan tersebut meliputi: perencanaan tindakan, pelaksanaan tindakan, observasi dan refleksi. Penelitian ini dilaksanakan di SMP Negeri 2 Sukodono yang berlokasi di jalan Dieng no 272 Kabupaten 
Lumajang. Subyek penelitian ini adalah kelas VIII. Karena banyaknya jumlah kelas, serta kurangnya pemahaman siswa dalam menyelesaikan suatu masalah maka peneliti hanya mengambil satu kelas saja. Pengumpulan data dalam penelitian ini dilakukan dengan menggunakan 3 cara sesuai dengan kebutuhan peneliti, yaitu (1) observasi atau catatan lapangan; (2) dokumentasi; dan (3) tes. Data yang telah terkumpul kemudian dianalisis. Analisis data bertujuan untuk mengungkap data apa yang masih perlu dicari, pertanyaan apa yang masih belum dijawab, metode apa yang harus digunakan untuk mendapatkan informasi baru, dan kesalahan apa saja yang harus segera diperbaiki. Analisis data dilakukan setiap kali pemberian tindakan berakhir dan sesudah pengumpulan data. Analisis data dalam penelitian tindakan kelas menurut Suyanto, dkk (2006:12) meliputi 3 tahapan, yaitu reduksi data, laporan data, dan penyimpulan hasil analisis.

\section{HASIL DAN PEMBAHASAN}

Pada tahap observasi 1 Pada tahap ini, kegiatan yang dilaksanakan adalah mengamati proses pembelajaran siswa yang dilakukan oleh dua rekan peneliti dan guru bidang studi Geografi SMP Negeri 13 Malang. Berdasarkan hasil pengamatan diperoleh beberapa temuan penelitian setelah pelaksanaan tindakan pada Siklus 1, yaitu: Masih ada siswa yang bingung dengan model pembelajaran berbasis masalah terlihat dari beberapa siswa yang sering bertanya kepada guru, Tidak semua siswa mempunyai buku sumber karena guru tidak menganjurkan siswa untuk mempunyai satu buku pegangan tertentu. Kondisi seperti ini yang menyebabkan banyak siswa yang lalu lalang untuk meminjam buku pada teman lain yang mempunyai buku sumber, Masih ada 4 anggota kelompok belajar yang pasif, bergurau sendiri, dan tidak mau berdiskusi dalam mengerjakan tugas dari guru, Masih ada 2 anggota kelompok yang tidak memperhatikan temannya saat mengajukan pertanyaan maupun menjawab pertanyaan ketika diskusi kelas berlangsung, Siswa mempresentasikan diskusinya dengan ragu-ragu dan Guru berkeliling dari kelompok satu ke kelompok yang lain, untuk memberipenjelasan kepada kelompok lain yang belum jelas tentang tugas yang diberikan. dapat diketahui bahwa trejadi peningkatan persentase aktivitas belajar siswa pada masing-masing aspek aktivitas belajar siswa yang diamati. Aspek penguasaan materi meningkat dari $61,66 \%$ pada siklus I menjadi $90 \%$ pada siklus II, aspek penyampaian materi meningkat dari $57,92 \%$ pada siklus I menjadi $82,91 \%$ pada siklus II, aspek bertanya meningkat dari $60,17 \%$ pada siklus I menjadi $69,83 \%$ pada siklus II, aspek berkomentar meningkat dari $74,17 \%$ pada siklus I menjadi $80,83 \%$, aspek menjawab meningkat dari $49,17 \%$ pada siklus I menjadi $72,25 \%$ pada siklus II dan aspek aktivitas lain meningkat dari 75,42\% pada siklus I menjadi $77,08 \%$ pada siklus II. secara keseluruhan persentase aktivitas belajar siswa dan taraf keberhasilan tindakan meningkat dari $65,07 \%$ atau memiliki taraf keberhasilan cukup pada siklus I menjadi 76,67\% atau memiliki taraf keberhasilan baik pada siklus II, dan dari hasil yang diperoleh pada siklus II dapat disimpulkan bahwa adanya peningkatan yang signifikan pada persentase taraf keberhasilan untuk aktivitas belajar siswa dan ini membuktikan bahwa Penerapan Pembelajaran Berbasis Masalah dapat Meningkatkan Aktivitas Belajar Siswa dalam Memecahkan Masalah Lingkungan Hidup Pada Mata Pelajaran Geografi Di SMP Negeri 2 Sukodono.

\section{PENUTUP}

\section{Kesimpulan}

Berdasarkan hasil penelitian, analisis data dan pembahasan penelitian diperoleh kesimpulan bahwa pembelajaran geografi dengan menggunakan model pembelajaran berbasis masalah dapat meningkatkan pemahaman siswa terhadap permasalahan lingkungan hidup. Metode pembelajaran dengan menggunakan model pembelajaran berbasis masalah dapat meningkatkan hasil belajar siswa, pada siklus I nilai rata-rata 67,92. pada siklus II rata-rata hasil belajar siswa adalah 72,5 serta dapat pula 
meningkatkan aktivitas belajar siswa pada siklus I keberhasilan tindakan sebesar 65,07\% (cukup) dan pada siklus II meningkat menjadi 76,67\% (baik). Aktivitas belajar yang paling menonjol adalah aspek penguasaan materi dan aspek tanya jawab.karena mengalami peningkatan dari siklus I ke siklus II sebesar $28,34 \%$.

\section{Saran}

Berdasarkan kesimpulan di atas maka dianjurkan beberapa saran yang perlu dipertimbangkan sebagai berikut:

a. Bagi guru mata pelajaran geografi dalam pembelajaran geografi perlu dilakukan dengan menggunakan model pembelajaran berbasis masalah karena ini sangat mendukung untuk kemampuan berfikir kritis serta menimgkatkan kecerdasan dan hasil belajar.

b. Hendaknya memperhatikan jumlah permasalahan yang diberikan kepadansiswa karena salah satu kelemahan dalam model pembelajaran berbasis masalah adalah membutuhkan waktu yang panjang serta hendaknya memperhatikan pengelolaan waktu agar proses pembelajaran dapat bejalan sesuai dengan rencana pelaksanaan pembelajaran.

\section{DAFTAR PUSTAKA}

Dahar, Ratna Willis. 2014. Teori-teori Belajar. Jakarta: Erlangga

Demirel, M. \& Arslan, B. 2010. The Effects Of Problem Based Learning On Achievement, Attitude, Metacognitive Awareness and Motivation. Journal of Education. 38 (1): 55-66

Dimyati\&Mudjiono. 2006. Belajar dan Pembelajaran.Jakarta: Rineka Cipta.

Djamarah, Syiful. 2006. Strategi Belajar Mengajar. Jakarta: PT Rineka Cipta.

Hamalik, Oemar. 2001. Proses Belajar Mengajar. Jakarta: PT. Bumi Aksara.

Hamid, Abdul. 2010. Pelaksanaan Proses Perkuliahan Mekanika Pada Semester Pendek Berdasarkan Pada Masalah (Problem Based Learning) Dengan Pendekatan Kooperatif. Jurnal pendidikan FKIP Universitas Syiah Kuala. Vol 7(2):61-125

Harison, Bob. 2007. What is Problem Based Learning. California: Sierra Training Associates Inc.

Hasanah, Nur. 2012. Pengaruh Penerapan Problem Based Learning melalui Strategi Belajar Preview, Question, Read, Reflect, Recite, and Review terhadap Kemampuan Berpikir Kritis, Hasil Belajar Kognitif, dan Hasil Belajar Afektif Siswa Kelas VII SMPN 18 Balikpapan. Tesis tidak diterbitkan. Malang: Universitas Negeri Malang.

Hmelo-Siver, Cindy. 2004. Problem Based Learning: What and How Do Students Learn. Educational Psychology Review, 16 (3): 235-266

Hmelo-Silver, Cindy . 2011. In Memoriam: Remembering Howard S. Barrows. Interdisciplinary Journal of Problem-based Learning, 5 (2): 6-8

Hung, Woei et al. 2008. Problem Based Learning. The Interdisciplinary Journal of Problem Based Learning, I (38): 486-506

Ibrahim, M. \& Nur, M. 2000. Pengajaran Berdasarkan Masalah. Surabaya: Unesa University Press Jogiyanto, 2006. Filosofi, Pendekatan dan Penerapan Pembelajaran Metode Kasus. Yogjakarta: Andi

Karmana, I Wayan, 2010. Pengaruh Strategi PBL dan Integrasinya dengan STAD terhadap Kemampuan Pemecahan Masalah, Kemampuan Berpikir Kritis, Kesadaran Metakognitif, dan Hasil Belajar Biologi pada Siswa Kelas X SMA Negeri 4 Mataram. Tesis tidak diterbitkan. Malang: Universitas Negeri Malang. 
Kate, Adams. 2009. Introducing problem based learning to third year B.Ed. students and their tutors. Journal of Teacher Education and Teachers' Work, 1 (1)

Koestiningsih, Noer. 2010. Perbedaan Hasil Siswa yang Belajar dengan Menggunakan Strategi Problem Based Learning (PBL) dan Konvensional Siswa Kelas X di SMKN 1 Blitar. Tesis tidak diterbitkan. Malang: Universitas Negeri Malang.

Kolmos, Annete et al.2007. Problem Based Learning. Selahattin Kuru: TREE Isik University.

Lestari, Dina. 2012. Pengaruh Model Pembelajaran Problem Based Learning terhadap Hasil Belajar IPA Siswa Kelas VIII SMPN 2 Blitar ditinjau dari kemampuan Dasar Matematika. Tesis tidak diterbitkan. Malang: Universitas Negeri Malang.

Lie, Anita. 2010. Cooperative Learning: Mempraktikan Cooperative Learning di Ruang-ruang kelas. Jakarta: PT Gramedia Widiasarana Indonesia.

Made, Ni Suci. 2008. Penerapan Model Problem Based Learning Untuk Meningkatkan Partisipasi Belajar dan Hasil Belajar Teori Akuntansi Mahasiswa Jurusan Ekonomi UNDIKSHA. Jurnal Penelitian dan Pengembangan Pendidikan FIS UNDIKSHA. Vol 2(1), 74-86

Malikha. Dyan Rifiana. 2012. Pengaruh Strategi Problem Based Learning Berbantuan Multimedia dan Kemampuan Akademik terhadap Kemampuan Berpikir Kritis dan Hasil Belajar IPA Siswa Jurusan Mesin SMKN 1 Jenangan Ponorogo. Tesis tidak diterbitkan. Malang: Universitas Negeri Malang.

Mahanal, Susriyati \& Zubaidah. 2007. Penerapan Pembelajaran Berdasarkan Masalah dengan Strategi Kooperatif Model STAD pada Mata Pelajaran Sains untuk Meningkatkan Kemampuan Berfikir Kritis Siswa Kelas V MI Jenderal Sudirman Malang. Jurnal Penelitian Kependidikan, 17 (1): 32-47.

Nurhadi, dkk. 2004. Pembelajaran kontekstual dan penerapanya dalam KBK. Malang: UM Malang.

Nursamsu. 2013. Efektivitas Penerapan Model Pembelajaran Problem Based Learning (PBL) dan Jigsaw terhadap Hasil Belajar ditinjau dari Motivasi. Tesis tidak diterbitkan. Malang: Universitas Negeri Malang

Purwanto, Edy. 2005. Evaluasi Hasil Belajar. Malang: Universitas Negeri Malang.

Rosmalinda, Rita 2014. Pengaruh Model Pembelajaran Problem Based LearningTerhadap Kemampuan Berpikir Kritis Siswa Sma Negeri 7 Bandar Lampung. Tesis tidak diterbitkan. Malang: Universitas Negeri Malang.

Rusman. 2013. Model-Model Pembelajaran. Bandung: Raja Grafindo Persada

Rusmono, 2012. Strategi pembelajaran dengan Problem Based Learning itu Perlu. Bogor: Galia Indonesia.

Sari \& Nasikh. 2009. Efektivitas Penerapan Pembelajaran Berbasis Masalah dan Teknik Peta Konsep dalam Meningkatkan Proses dan Hasil Belajar Mata Pelajaran Ekonomi Siswa Kelas X-6 SMAN 2 Malang Semester Genap Tahun Ajaran 2006-2007. Jurnal Penelitian Pendidikan Ekonomi FE UM. Vol 2(1)

Sardiman, A.M. 2001. Motivasi Belajar Mengajar. Jakarta: Raja

Sanjaya, W. 2011. Strategi Pembelajaran Berorientasi Standar Proses Pendidikan. Jakarta: Kencana Prenada Media.

Slameto. 2003. Belajar dan Faktor-faktor yang Mempengaruhinya. Jakarta: Bumi Aksara.

Slavin \& Baden. 2003. Facilitating Problem based Based Learning. Philadelphia: McGraw-Hill Education SRHE and Open University Press

Savery, John. 2006. Overview of Problem-based Learning: Definitions 
and Distinctions. Interdisciplinary Journal of Problem-based Learning, 1 (3); 9-20

Sudarman. 2007. Problem Based Learning: Suatu Model Pembelajaran untuk Me-ngembangkan dan Meningkatkan Kemampuan Memecahkan Masalah. Jurnal Pendidikan Inovatif, 2 (2); 73-8.

Sudjana, Nana \& Ahmad Rivai. 2003. Teknologi Pengajaran. Bandung: Sinar Baru Algensindo.

Sudjana, Nana. 2010. Penilaian hasil proses belajar mengajar. Bandung: PT. Remaja Rosdakarya.

Sugiyono. 2010. Metode Penelitian Pendidikan. Alfabeta: Bandung 